\title{
A talaj, mint multifunkcionális erőforrás (Multifunctional soil resources)
}

(XIV. Alpok-Adria Tudományos Tanácskozás, Neum, Bosznia-Hercegovina 2015. május 11. - május 16.)

Az életminőség három legfontosabb kritériuma az egészséges jó minőségü táplálék, a tiszta víz és a kellemes környezet (VÁRALLYAY, 2015). Mindhárom szoros összefüggésben van a természeti erőforrások ésszerü és fenntartható használatával; a talaj, a víz és a táj védelmével, állapotának megőrzésével és fenntartásával.

A talajnak, mint feltételesen megújuló erőforrásnak különleges szerepe van e célok megvalósításában, a társadalom egyre inkább veszi igénybe. A fenntartható fejlődés egyre inkább épít a talaj különböző funkcióira, amelyek közül legfontosabbak a következök (VÁRALLYAY, 2001):

- Feltételesen megújuló természeti erőforrás.

- A többi természeti erőforrás (sugárzó napenergia, légkör, felszíni és felszín alatti vízkészletek, biológiai erőforrások) hatásának integrátora, transzformátora, reaktora. Ily módon biztosít életteret a talajbani élettevékenységnek, termőhelyet a természetes növényzetnek és a termesztett kultúráknak.

- A primer biomassza-termelés alapvető közege, a bioszféra primer tápanyagforrása.

- Hő, víz és növényi tápanyagok természetes raktározója.

- A talajt (és a terresztris ökoszisztémákat) érő, természetes vagy emberi tevékenység hatására bekövetkező stresszhatások puffer közege.

- A természet hatalmas szürő- és detoxikáló rendszere.

- A bioszféra jelentős gén-rezervoárja, a biodiverzitás nélkülözhetetlen eleme.

- Történelmi örökségek hordozója.

E funkciók fontossága, jelentősége, "súlya" térben és időben egyaránt változott és változik ma is. Hosszú időn keresztül csak a biomassza-termeléssel kapcsolatos funkciók voltak fontosak, míg az utóbbi években különösen felértékelődtek a környezet minőségével kapcsolatos funkciók is.

A talaj-környezet kölcsönhatás kétoldalú. A talaj egyrészt "elszenvedi" a környezet gyakran káros stresszhatásait, másrészt - elsősorban ésszerütlen használata esetén - okoz(hat) is ilyeneket, fenyegetést jelentve környezetünk többi elemére: a felszíni és felszín alatti vízkészletekre, a felszín közeli légkörre, az élővilágra és a tájra.

2015-ben az Alpok-Adria tudományos együttmüködés keretei között megrendezett $14^{\text {th }}$ Alps-Adria Scientific Workshop témája a talajok multifunkcionalitása volt. A témaválasztás szorosan illeszkedett a korábbi tudományos tanácskozások sorába. 
Mint ismeretes az Alpok-Adria konferenciák minden esetben tematikusak, feladatuk egy-egy szükebb szakterület alapos feltárása, megvitatása, e területek újabb kutatási eredményeinek áttekintése.

A $14^{\text {th }}$ Alps-Adria Scientific Workshop résztvevői igen széleskörű kutatási bázison született tudományos eredmények tükrében tekintették át a talaj multifunkcionális rendszerének talajtani, földmüvelési, növénytermesztési, élettani, biokémiai, botanikai, környezettudományi, valamint gazdasági kérdéseit. Érdemes áttekinteni a tanácskozás helyét, szakmai kapcsolódását a konferenciasorozat tükrében.

A Magyar Tudományos Akadémia Agrártudományok Osztályának több bizottsága által alapított együttmüködés és az azóta is évente megszervezett konferencia napjainkra a térség egyik legnagyobb és egyben - elfogultság nélkül is állítható, hogy - legnépszerübb tudományos eseményévé nőtte ki magát az agrártudományok területén (JOLÁNKAI, 2009).

\section{1. táblázat}

A tudományos tanácskozások helyszíne és témája

\begin{tabular}{|c|c|}
\hline A tanácskozás éve, helyszíne & A tanácskozás témája \\
\hline 2002. Abbáz & Agri-environment (Agrár környezet) \\
\hline 2003. $\mathrm{T}$ & $\begin{array}{l}\text { Plant nutrition. Nitrogen - a most essential life element } \\
\text { (Növénytáplálás. Nitrogén - } \\
\text { a lényegi esszenciális elem) }\end{array}$ \\
\hline $\begin{array}{l}\text { 2004. Dubrovnik, Horvátor- } \\
\text { szág }\end{array}$ & $\begin{array}{l}\text { Water. Soil, plant and biological relations, climatic } \\
\text { aspects (A víz. Talaj, növény és biológiai kapcsolatai, } \\
\text { klimatikus szempontjai) }\end{array}$ \\
\hline 2005. Portorož, Szlovénia & The carbon cycle (A karbon ciklus) \\
\hline 2006. Abbázia, Horvátország & $\begin{array}{l}\text { Food chain element transport and processes (A táplálék- } \\
\text { lánc elemtranszportja és annak folyamatai) }\end{array}$ \\
\hline 2007. Obervellach, Ausztria & $\begin{array}{l}\text { Environmental consequences of sustainability (A fenn- } \\
\text { tarthatóság környezeti következményei) }\end{array}$ \\
\hline 2008. Stará Lesná, Szlovákia & Soil-plant interrelations (Talaj-növény kapcsolatok) \\
\hline $\begin{array}{l}\text { 2009. Neum, Bosznia- } \\
\text { Hercegovina }\end{array}$ & $\begin{array}{l}\text { Biotic and abiotic stress (A biotikus és az abiotikus } \\
\text { stressz) }\end{array}$ \\
\hline 2010. Špičák, Csehország & $\begin{array}{l}\text { Resilience within agro-ecosystems }(\mathrm{Az} \text { agroöko- } \\
\text { szisztémák megújulása) }\end{array}$ \\
\hline 2011. Abbázia, Horvátország & $\begin{array}{l}\text { Crop site - land use synergism (A termöhely és a föld- } \\
\text { használat szinergizmusa) }\end{array}$ \\
\hline 2012. Szomolány, Szlovákia & Green water (Zöld víz) \\
\hline $\begin{array}{l}\text { 2013. Abbázia-Doberdó- } \\
\text { Velence, Horvát-ország } \\
\text { - Olaszország }\end{array}$ & Soil fertility (Talajtermékenység) \\
\hline $\begin{array}{l}\text { 2014. Villach Ossiacher See, } \\
\text { Ausztria }\end{array}$ & $\begin{array}{l}\text { Manures and fertilizers(A szervestrágyázás és a mütrá- } \\
\text { gyázás) }\end{array}$ \\
\hline $\begin{array}{l}\text { 2015. Neum, Bosznia- } \\
\text { Hercegovina }\end{array}$ & $\begin{array}{l}\text { Multifunctional soil resources (A talaj, mint multifunk- } \\
\text { cionális erőforrás) }\end{array}$ \\
\hline
\end{tabular}


A tanácskozás-sorozat lényegében egy folyamatosan egymásra épülő, tematikus rendszerben alakítja ki programját és teremt fórumot az adott terület tudományos kutatási eredményeinek bemutatására, azok megvitatására. Az 1. táblázat az eddigi tudományos tanácskozások helyszíneit és témáit foglalja össze.

A 2015. évi konferenciára a rendezvénysorozat történetében második alkalommal Neumban került sor a Hotel Zenit konferenciaközpontjában. A tudományos tanácskozáson a térség országai agrokémiai és talajtani, hidrológiai, élettani, ökológiai, növénytermesztési és növényvédelmi oktató és kutató közösségének összesen 155 tagja számolt be kutatási eredményeiröl. A konferencia témája megfelelő módon illeszkedett az eddigi tanácskozások tematikus sorozatába: „A talaj, mint multifunkcionális erőforrás" (Multifunctional soil resources) egy olyan témakör, amelynek ismeretanyaga folyamatosan változott az elmúlt évszázad során, és napjainkban is újabb és újabb hatásoknak, illetve értelmezésbeli átformálásnak van kitéve (JOLÁNKAI et al., 2010). A konferencia másik alapvető feladata az volt, hogy a térség agrárkutatóinak részvételével megvitassuk e szakterület kutatási eredményeit, keressük a kapcsolódási pontokat, valamint megvessük alapjait olyan tudományos együttmüködéseknek, amelyek részét képezhetik a térség agráriuma fejlesztési feladatainak. Az előadások egy plenáris és hat tematikus szekcióban hangzottak el. Ezt egészítette ki egy záró kerekasztal vita (wrap up), amely során megfogalmazásra kerültek az egyes szekciók előadásainak konklúziói, posztulátumai. A rendezők, követve a villachi konferencia sikeresnek bizonyult szervezési rendjét, nem szerveztek külön poszter szekciókat, hanem az egyes poszterek rövid bemutatására a szerzők az adott tematikus szekcióban kaptak lehetőséget. Ez a módszer Neumban is bizonyította sikerességét, lehetőséget adva a fiatal kutatóknak a tudományos közegben való oldottabb szereplésre.

A tanácskozást Nagy János nyitotta meg. Ezt követően Jolánkai Márton tartotta a konferencia key-note előadását, amely rövid összefoglalását adta a témakörnek. Ezt követően négy plenáris előadás ismertette az egyes érintett szakterületek talaj multifunkcionalitással kapcsolatos problémáit, melynek előadói, illetve szerzői Várallyay György, Čustović Hamid, Ljuša Melisa, Taletović Jasmin, Tvica Mirza, Smutny Vladimir, Dvortelova Hana, Lukaš Vojtech, Brotan Jan, Sedek Antonin, Velisková Yvetta, Dulovicová Renáta és Dušek Petr voltak. A tanácskozás egyes szekciói, illetve azok elnökei és moderátorai a következők voltak:

- Növény I:

- Növény II:

- Talaj I:

- Talaj II:

- Környezet I:

- Környezet II:

- Kerekasztal vita:

A konferencia záróünnepségén Nagy János professzor úr, a Magyar Tudományos Akadémia Talajtani, Vízgazdálkodási és Növénytermesztési Bizottsága nevében köszöntötte a konferencia résztvevöit, és megköszönte a szervezők és a házigazdák munkáját. Ezt követően átadta a konferencia elismerő okleveleit, amelyeket a legtehetségesebb fiatal kutatók kaptak meg. 
A hagyományoknak megfelelően a konferencia szerves részét képezték a szakmai és turisztikai kirándulások, amelyek érdekes és tanulságos élményt jelentettek a résztvevőknek. Az első program egy hajoúttal egybekötött kirándulás volt a Neretva delta polderei közötti csatornákon, amelyek során narancsültetvényeket, valamint zöldségtermesztő szigeteket lehetett megtekinteni. Az út során lehetőség nyílt egy katavotra megtekintésére is, amelynél Hoyk Edit tartott szakszerü, ugyanakkor mindenki számára érthető hidrogeológiai ismertetést. A hajókirándulást változatos népzenei és gasztronómiai események egészítették ki. A második kirándulási nap különleges szakmai élményt kínált. A konferencia résztvevői látogatást tettek az UNESCO világörökséghez tartozó Vjetrenicai cseppkőbarlangban, valamint a közeli ortodox kolostorban. A kirándulás végén a résztvevők megtekinthették Stone város középkori erődítményeit, amelyek a mediterrán térség egyik legnagyobb kiterjedésü középkori építészeti emlékét alkotják.

A konferencia előadásai a Növénytermelés folyóirat 64. évfolyamának Supplementum köteteként a konferencia megnyitásával egyidejüleg kiadásra kerültek. A kötet $\mathrm{CD}$ változatát minden résztvevő a regisztráció alkalmával megkapta. A konferenciakötet DOI számmal ellátott open access változata az interneten is elérhetö (DOI:10.12666/Novenyterm.64.2015.Suppl). A kötetet Kende Zoltán szerkesztette. Végezetül, de nem utolsó sorban e helyen is köszönetet szükséges mondani a konferencia házigazdáinak Čustović Hamid professzornak és Lakić Ivan igazgató úrnak, valamint a tanácskozás magyar szervezőinek és munkatársainak a több mint egy évet felölelő munkájukért, amelyet az előkészítés és a lebonyolítás területén végeztek, és amely meghatározó jelentőségű a rendezvénysorozat eljövendő konferenciái számára is. E sorok írásakor már folyik a jubileumi 15. konferencia szervezése, amelyre a horvátországi Mali Losinjban kerül sor 2016-ban.

\section{Irodalom}

JOLÁNKAI M., 2009. Az Alpok-Adria tudományos együttmüködés - a térség agrárkutatásának fóruma. Magyar Tudomány. 170. (4) 485-489.

JoLÁNKAI, M., NYÁRAI, F. H. \& KASSAI, K., 2010. Impact of long term trials on crop production research and education. Acta Agronomica Hungarica. 58. Suppl. 1-5.

VÁRALlYAY G., 2001. A talaj vízgazdálkodása és a környezet. Magyar Tudomány. 162. (7) $437-444$.

VÁRALlyay, Gy., 2015. Multifunctionality of soils. Növénytermelés. 64. Suppl. 11-14.

Érkezett: 2016. január 1.

JOLÁNKAI Márton, KASSAI M. Katalin és TARNAWA Ákos

Postai cím: JOLÁNKAI MÁRTON, Szent István Egyetem, Növénytermesztési Intézet, 2103 Gödöllő, Páter K. u. 1. E-mail: jolankai.marton@mkk.szie.hu 